DOI $10.31651 / 2524-2660-2020-4-78-82$

ORCID 0000-0001-5698-6989

\title{
ZHELIASKOV Vasyl,
}

Doctor in Pedagogy, Associate Professor, Head of the Department of Humanities, Danube Institute of the National University "Odessa Maritime Academy" e-mail: zhelvas72@gmail.com

UDC 378.51.004.42: 316.472.4(045)

\section{USE OF INFORMATION AND COMMUNICATION TECHNOLOGIES IN THE PROFESSIONAL LANGUAGE TRAINING OF FUTURE NAVIGATORS}

The article deals with the problem of influence of the information environment on navigators' professional activity. It is emphasized that it is a topical issue in the system of higher marine education. It was clarified that at the present stage of training of marine specialists one of the most urgent problems is professional interaction in the process of professional activity. The safety of navigation, as well as the lives of passengers, depend on how effectively a navigator can communicate with crew members, and his level of professional interaction. In the process of professional interaction, navigators face a variety of non-standard and unpredictable situations which require new decisions and communicative understanding. In the study it was noted that the vast majority of vessels have multilingual inter?ational crews, which sometimes are not able to demonstrate necessary professional skills for various reasons, including lack of English, thus endangering passengers, companies, property and environment. An important role is played by professional communicative interaction, which is extremely important for the safety of sea trans?ortation. It is emphasized on the improvement of the process of teaching professional communicative interaction based on the introduction of elements of blended learning.

Keywords: information and communication technologies; blended learning; foreign language; interactive approach.

Formulation of the problem. Improving the study process of future navigators to professional communicative interaction is based on the introduction of innovative technologies, including ICT-based methods with the elements of blended learning in this process. Information and communication technologies involving the Internet, social networks and software and computer systems provide a wide range of opportunities for the new gen- eration of navigators to expand marine knowledge and information through a global system that goes beyond narrow contexts. Such knowledge is characterized by a variety of sources, they unite the culture of different peoples, cover the global information infrastructure and areas of human activity such as politics and economics, science and technology, culture and education. There are several approaches that can be applied in the process of learning foreign languages. One of the ways to improve the educational process aimed at mastering professional communicative interaction is to combine traditional learning and elements of blended learning.

Analysis of recent research and publications. The pedagogical process is constantly enriched with new ways of operating the received information, a creative approach to solving science issues with an emphasis on the individualization of educational programs. This can be applied to different working activities. In the study which was conducted by O. Moskalenko, it is noted that different unforeseen air situations often occur, and the pilot does not have accurate information about who he is communicating with, who is controlling the air traffic, and what his further actions and decisions are related to. In extreme situations, when time is counted in seconds, knowledge of technical terms and concepts in English allows you to correctly report an obvious or emergency situation, to make a timely and correct decision. The main trends in the improvement of educational technologies are characterized by the transition from the focus on the average student to individualized training programs. In such conditions, the teacher, who per- 
forms the function of a "technologist" of the educational process, needs to use innovative technologies, ideas, directions [1, p. 235].

For training of aviation professionals by means of ICT O. Didenko, O. Moskalenko suggest a computer tool for training pilots' listening skills in Aviation English. In particular, they offer a special technology based on various computer exercises which are used to enhance the learners' level of English as well as improve their listening skills. It should be mentioned that English is one of the crucial factors influencing flight safety. Pilot's ability to listen, hear, interpret and react to controller's information in English is of paramount importance during radio communication [2].

The problem of training of future border guard officers by means of information and communication technologies is also discussed by many scholars. We support the ideas of the authors S. Bilyavets, O. Didenko, D. Kuprienko, O. Moskalenko that the practical significance of the use of the proposed ICT is that it activates cognitive activity of cadets and contributes to the development of memory, attention, and professional observation skills. Due to the peculiarities of the content training of future border guard officers and the importance of high level of their knowledge, abilities and skills at the border crossing points, the use of the electronic didactic modular environment of the academic discipline "Provision of border control" has been offered. This environment is an informational and on-line resource based on the local computer network of the higher educational institution [3, p. 87].

T. Gerasymchuk, researching the use of information technology in the formation of professional foreign language competence of future engineers of the road industry, concludes that professional computer knowledge and skills are extremely important for engineers in the modern dimension of computerization of road professional field [4, p. 33-34].

In professional training of marine specialists L. Gerganov claims that the use of ICT helps to move away from traditional forms of teaching and overcome the monotony of the classroom during the formation of speech and communicative competence of students in the classroom. ICT can be considered as a set of methods, tools and techniques used to select, process, store, present, transmit various data and materials needed to improve the efficiency of various activities [5].

The purpose of the article is to analyze the use of information and communication technologies in the professional language training of future navigators at higher marine educational institutions.
The main material. In the context of learning professional communicative interaction for navigators, blended learning technologies play an essential role. In the process of professional training of future navigators, universities focus on international standards presented in the "International Convention on the Training and Certification of Seafarers and Watchkeeping" [6], which outlines the mandatory requirements for the certification of various categories of seafarers - captains, senior and junior officers, ship mechanics, electromechanics, etc. In modern conditions of intensification of sea transportations, it is possible to reach a proper level of preparation thanks to introduction of distance learning, development of online courses, improvement of effective technologies of blended learning.

The main professional requirements to maritime specialists are also provided in the professional documents regulating the process of professional communicative interaction in English for future navigators - the European Recommendations on language education, the English language framework for professional communication and Model courses of the International Maritime Organization - 3.17 "Maritime English" [7], 1.39 "Leadership and Teamwork" [8] and 1.21 "Personal Security and Social Responsibility" [9]. These documents also deal with the necessity of thorough preparation of navigators to use of different navigational aids - simulators, GPS, electronic devices and tools. Thus, the study of the main principles of ICT with the elements of blended learning is very topical issue in marine field.

Many terms have recently been introduced into the modern scientific community, which use the meaning of "blended learning", i.e. combining computer learning with classroom learning with a teacher: information technology, ICT, network technology, digital technology, etc. In the context of the study ICT can be used in English classes to teach professional communication interaction of future navigators.

Information and communication technologies are widely used in marine training that have a significant positive impact on education, because: they open wide opportunities for access to the necessary information sources; create conditions for the rapid transfer of information and learning, the development of practical skills and abilities; increase resources for the development of creative potential of students; optimize the learning process, ensure its efficiency and 
flexibility; enable the introduction of new teaching methods in marine study process.

The potential of application of information network technologies at higher marine educational establishments consists in creation of convenient conditions of training: flexibility of the educational schedule; saving time; no need to attend consultations; interactivity of learning, the ability to communicate with the teacher via the Internet; individual approach and taking into account the individual level of training; reporting that helps students control their own academic achievements. We could note that in the planning of independent work with the use of ICT of particular importance is the clear organization of the educational process of students by the institution and its careful planning by the teacher.

In our study we can define the following characteristics of blended learning: blended learning is a purposeful process of acquiring knowledge, skills and abilities within a certain academic discipline, part of which is implemented in distance mode; blended learning is implemented through ICT and SCI (computers, mobile phones, projectors, tablets, etc.); ICT is used not only for the transfer of educational material, but also for the control and organization of educational interaction (consultations, discussions); students' self-control is provided.

Smart technologies open wide opportunities for self-development and disclosure of creative potential of future navigators. The organization of training with the help of smart technologies provides flexibility, individualization, interactivity of the learning process, a combination of individual and group classes. Modern Internet and smart technologies open wide access to educational services in marine service. Mobile technologies have transformed and simplified people's lives, made the learning process more interesting and accessible, and have become indispensable assistants in acquiring knowledge. At the same time, new opportunities have led to new difficulties in work. Smartphones are evolving rapidly, taking on many device management functions; the growth of information flows and the increase in the area of its display on the display led to the emergence of more powerful processors and graphics chipsets.

In the opinion of O. Moskalenko ICT includes the use of Skype, Zoom, Google Meet that can stimulate language learning: cadets had the opportunity not only to exchange phrases, but also to hear and see each other, to practice pronunciation, speaking skills, lexical skills. The biggest advantage of the resource is the simplicity and accessibility of the service, the ability to establish intercultural connections, to overcome psychological barriers to a foreign language. Group discussion forums can be provided through these technologies to discuss specific aviation issues. Cadets should be invited to participate in the aviation forum, where they discuss non-standard takeoffs, landings, taxiing at an unfamiliar airport, extreme flight conditions. As you know, students are the most active users of the Internet, so it is extremely important not to "overdose" work, so as not to cause Internet addiction. Chat and online games are often becoming an increasingly desirable way to spend free time, replacing basic cognitive activities [10, p. 329].

ICT also includes mobile learning ( $\mathrm{m}$ learning) - the use of portable IT devices, PDAs (mobile Digital Assistants), mobile phones, laptops and tablets. There are several approaches to the definition of the term "mobile learning":

- "m-learning" is a type of distance learning in which knowledge is transferred to the technical devices of students (mobile phone, laptop or PDA); the methods of transmitting information may be different;

- "m-learning" is the transfer of knowledge to a mobile device via WAP or GPRS over the Internet;

- "m-learning" is an educational technology by which the organization of the learning process takes place through mobile devices, such as mobile phones and communicators (with the possibility of access to the Internet is optional).

- In our opinion, the introduction of mobile technologies in the study of future navigators has the following advantages:

- participants in the educational process can move freely;

- technologies expand the boundaries of the educational process outside the educational institution;

- economic justification, which proves the non-necessity of having a personal computer;

- flexibility and mobility - participants in the educational process can effectively manage their time;

- providing fast exchange of information due to modern wireless technologies (GPRS, Bluetooth, Wi-Fi, Viber, Skype);

- increasing interest in learning, as the information is presented in a multimedia format.

As a result of the analysis of practical experience of using blended learning in educa- 
tion, V. Fandei presented three models of blended learning: 1) supportive; 2) replacement; 3) model of electronic educational center [11].

The supportive model of blended learning is aimed at supplementing traditional distance learning (this can be the performance of individual group or individual tasks in a computer environment, the development of a computer training program, etc.). According to this model, with the introduction of distance learning, the format of the course changes: maintaining the number of classroom hours, increasing the amount of material allows you to increase the amount of time planned for independent work with the use of ICT. At the same time, the teacher is able to better control the individual learning process of each student (due to feedback - an integral part of distance learning).

The replacement model provides for the full integration of e-learning resources in the training course, resulting in a change in the format of the course as a whole (division into distance and full-time components, the percentage of each of which can vary from $30 \%$ to $70 \%$ ). If the initial content of training is preserved, the classroom hours are reduced and the amount of time provided for independent work is increased. The division into face-to-face and distance components leads to a change in the forms of work in classroom and network classes.

The e-learning center model envisages the creation of university computer labs and an information educational environment that will be able to completely change the perception of forms of learning in the future. In the process of learning according to this model, traditional classroom classes are replaced by compulsory classes in the form of group and individual consultations conducted in a computer laboratory. The roles of participants in the pedagogical process are also changing: the teacher becomes a consultant-advisor who organizes and coordinates the educational process, rather than transmitting educational material, students become equal participants in this process.

It should be noted that all three described models of blended learning have the advantages. However, their implementation and successful functioning in education are possible in the presence of a developed infrastructure of the institution, pedagogically effectively designed classroom and independent work, qualified technical staff, sufficient information literacy of all participants in the pedagogical process, a high degree of auton- omy and stable motivation of students to study, cognitive activity high level of information security training.

Distance learning with the use of ICT technologies in the training of maritime specialists should be focused on the development of general and professional competencies, and not on the course of lectures and obtaining specific knowledge; to coordinate with different levels of preparation of students; be adapted to the individual needs of students. It is necessary to take care of the availability of remote materials from any device (computer, tablet, mobile phone) and from any network (local, global, satellite in sea conditions).

The implementation of ICT and the models of blended training of marine specialists is proposed on the basis of the Kherson State Maritime Academy and its Maritime College. For this purpose, the Laboratory of Innovative Technologies was established, which includes the Center for Assessment of Cadets' Academic Achievements. The laboratory provides traditional learning activities in the classroom under the guidance of an experienced teacher; various mechanisms for transferring educational materials (Internet, mobile networks, printed materials) and working with them (working with a glossary, wiki articles, adaptive testing, video tasks, etc.); structured self-study using online learning materials.

Conclusions. Thus, the use of ICT is especially effective in the study of marine navigators. In this case, it is very convenient to use portable devices to obtain information and new knowledge. Mobile devices provide new opportunities and a new learning environment; they complement teaching methods and become an important educational tool for teaching a foreign language. The potential of application of information network technologies consists in creation of convenient conditions of training: flexibility of the educational schedule; saving time; no need to attend consultations; interactivity of learning, the ability to communicate with the teacher via the Internet; individual approach and taking into account the individual level of training; reporting that helps students control their own academic achievements.

Prospects for further scientific research include the search for effective ways of implementing of simulator course for navigators as well as continuous professional ICT training of faculty staff taking into account their individual characteristics. 


\section{References}

1. Moskalenko, O. I. (2020). Humanitarian preparation of future aviation specialists by means of innovative technologies. Bulletin of Cherkasy National University. Series: Pedagogical Sciences, 3, 235-240. (in Ukr.).

2. Moskalenko, O., Didenko, O. (2018). A computer tool for training pilots' listening skills in Aviation English. Information Technologies and Learning Tools, 67(5), 187-198 (in Eng.).

3. Bilyavets, S.Ya., Didenko, O.V., Kuprienko, D.A., Moskalenko, O.I., Sychevsky, Yu.O. (2019). Application of information and communication technologies in the training of future border guards to identify vehicles and persons. Information Technologies and Learning Tools, 70(2), 86-103 (in Ukr.)

4. Gerasymchuk, T.V. (2015). Formation of professional foreign language competence of future engineers of automobile and road branch with use of information technologies: Theses of Ph.D Dissertation in Pedagogy. Kherson State University. 227 p. (in Ukr.)

5. Gerganov, L.D. (2016). Theoretical and methodical basics of professional training of skilled workers of a sea profile on manufacturing factories: Theses of Doctor Science Dissertation in Pedagogy. Kyiv: National Academy of Pedagogical Sciences of Ukraine, Institute of Vocational Education. 485 p. (in Ukr.)

6. International Convention Standards of Training, Certification and Watchkeeping for Seafarers, 1978 (STCW-78), as amended (consolidated text). (2010). St.Petersburg: CNSSMF. 806 p. (in Rus.).

7. Model Course 3.17. (2015). Maritime English. International Maritime Organization. London. 228 p. (in Eng.).

8. Model Course 1.39 (2014). Leadership and Teamwork. London: International Maritime Organization. 49 p. (in Eng.).

9. Model Course 1.21 (2000). Personal Safety and Social Responsibility. London: International Maritime Organization. 64 p. (in Eng.).

10. Moskalenko, O.I. (2017). Theoretical and methodical basics of preparation of students of higher flight educational institutions to professional communication in special conditions Theses of Doctor Science Dissertation in Pedagogy. Khmelnitsky: Khmelnitsky humanitarian and pedagogical academy. 590 p. (in Ukr.)

11. Fandey, V.A. (2011). Blended learning: current state and classification of blended learning models. Informatization of education and science, 4(12), 115-125. (in Rus.).

\section{Список бібліографічних посимань}

1. Москаленко О.І. Гуманітарна підготовка майбутніх фахівців авіаційної галузі із використанням інноваційних технологій. Вісник Черкаського націонаАьного університету (серія Педагогічні науки), 2020. № 3. C. 235-240.

2. Moskalenko O., Didenko O. A computer tool for training pilots' listening skills in Aviation English Information Technologies and Learning Tools, 2018. Vol 67, № 5. Рp. 187-198.

3. Білявець С.Я., Діденко О.В., Купрієнко Д.А., Москаленко О.І., Сичевський Ю.О. Застосування інформаційно-комунікаційних технологій у підготовці майбутніх офіцерів-прикордонників до ідентифікації транспортних засобів та осіб. Information Technologies and Learning Tools, 2019. Vol 70, № 2. Pp. 86-103.

4. Герасимчук Т.В. Формування професійної іншомовної компетентності майбутніх інженерів автомобільно-дорожньої галузі з використанням інформаційних технологій: дис. ... канд. пед. наук: 13.00.04. Херсон: Херсонський державний університет, 2015. 227 с.

5. Герганов $\Lambda$.Д. Теоретичні і методичні засади професійної підготовки кваліфікованих робітників морського профімю на виробництві: дис. ... д-ра пед. наук: 13.00.04. Київ: Національна академія педагогічних наук України, Інститут професійнотехнічної освіти, 2016. 485 с.

6. Международная конвенция о подготовке и дипломировании моряков и несении вахты 1978 г. (ПДМНВ-78) с поправками (консолидированный текст) / International Convention Standards of Training, Certification and Watchkeeping for Seafarers, 1978 (STCW-78), as amended (consolidated text). Санкт-Петербург: ЦНИИМФ, 2010. 806 с.

7. Model Course 3.17. Maritime English, 2015 Edition, International Maritime Organization. International Maritime Organization. London, 2015. 228 p.

8. Model Course 1.39. Leadership and Teamwork. London: International Maritime Organization (IMO), 2014. 49 p.

9. Model Course 1.21. Personal Safety and Social Responsibility. London: International Maritime Organization (IMO), 2000. 64 p.

10. Москаленко О.I. Теоретичні і методичні засади підготовки курсантів вищих мьотних навчальних закладів до професійної комунікації в особливих умовах : дис. ... д-ра пед. наук: 13.00.04. Хмельницький: Хмельницька гуманітарно-педагогічна академія, 2017. 590 с.

11. Фандей В.А. Смешанное обучение: современное состояние и классификация модемей смешанного обучения. Информатизаиия образования и науки, 2011. № 4 (12). C. 115-125.

\section{ЖЕАЯСКОВ Васимь Якович,}

доктор педагогічних наук, доцент, завідувач кафедри гуманітарних дисциплін,

Дунайський інститут національного університету "Одеська морська академія

\section{ВИКОРИСТАННЯ ІНФОРМАЦІЙНО-КОМУНІКАТИВНИХ ТЕХНОАОГІЙ У ПРОФЕСІЙНІЙ МОВНІЙ ПІДГОТОВЦІ МАЙБУТНІХ МОРСЬКИХ ФАХІВЦІВ}

У статті розглядаеться проблема впливу ІКТ на професійну діяльність майбутніх судноводї̈в. Актуалізовано питання мовної підготовки в системі вищої морської освіти. З'ясовано, шо на сучасному етапі підготовки морських фахівиів однією з найактуальніших проблем є професійна взаємодія в проиесі професійної діяльності. Безпека судноплавства, а також життя пасажирів залежать від того, наскільки ефективно судноводій може спілкуватися з иленами екіпажу, та від рівня його професійної взаємодї англійською мовою. у проиесі профресійної взаємодї судноводії стикаються з різними нестандартними ситуаиіями, які вимагають нових рішень та комунікативного розуміння. Зазначено, шо переважна більшість суден мають багатомовні міжнародні екіпажі, які іноді не здатні продемонструвати необхідні професійні навички з англійської мови. Наголошуеться на вдосконаленні процесу викладання професійної комунікативної взаємодї̈ на основі впровадження IKT технологій.

Ключові слова: інформаиійно-комунікаиійні технології; змішане навчання; іноземна мова; інтерактивний підхід. 